\title{
THE DISCOVERY OF GOLD OCCURRENCES IN EARLY TRIASSIC METATRACHYANDESITES AND THEIR ENCLAVES IN NNW KONYA/TURKEY
}

DOI: http://dx.doi.org/10.18509/GBP.2020.12

UDC: 553.411.062:550.42.08(560)

\author{
Kerim Kocak \\ Konya Technical University, Department of Geological Eng., Konya, Turkey
}

\begin{abstract}
Early Triassic trachyandesitic metavolcanic is located in Afyon zone, NW Konya. It includes relatively abundant enclaves, which are angular to spheroidal/ellipsoidal in shape, with host rock contact varying from straight/sharp to undulated/transitional. The enclaves with gold mineralizations are greenish to yellowish in color whereas gold-free enclaves have blackish to grayish colors. They contain both relict igneous (plagioclase, sanidine, clinopyroxene, hornblende and biotite) and overprinting metamorphic mineral assemblages (white mica, chlorite, Na-amphibole, epidote, sphene, and opaque oxides) in a hypocrystalline porphyritic texture.

The enclaves exhibit similarity to its host for its petrographical and petrological characteristics, with similar patterns in spider diagrams. Both metavolcanic and its enclave are predominantly metatrachyandesite in composition with alkaline affinity, exhibiting strong enrichment of LILE (e.g. 1.31-6.69 wt. $\% \mathrm{~K}_{2} \mathrm{O}$ ) and LREEs, and depletion of HFSE and HREEs, with negative $\mathrm{Eu}, \mathrm{Sr}, \mathrm{Nb}$, Ta and $\mathrm{Ti}$ anomalies. It was found out that the samples host gold, up to $1633 \mathrm{ppb}$ in enclaves, $\mathrm{Pb}$ and $\mathrm{Cu}$ mineralizations. The values determined could indicate existence of an economic gold mining in the region in relation with Triassic volcanism and magma mixing/mingling, and need further exploration studies.
\end{abstract}

Keywords: metatrachyandesite, enclave, gold, Konya

\section{INTRODUCTION\&GEOLOGICAL SETTING}

The study area that located in the Afyon-Bolkardagi Zone [1], (Figure 4a) contains "preMesozoic basement" overlaid unconformably by "Triassic to Tertiary cover series"'[2]. Lower Triassic metavolcanics forms as domes, lava flows, and volcaniclastics (Figure $4 b)$.

The enclaves are angular to spheroidal/ellipsoidal with various colours. The geometry of the enclave-host contact varies from straight/sharp to undulated/transitional.

The study area is part of the Tethyan Eurasian metallogenic belt (TEMB) [3]), extending from Europe through Anatolia to Iran, up to $13.000 \mathrm{~km}$ long. In the study area, the gold mineralisation has been found out in the enclave, and also its metavolcanic host rocks with lesser contents by bulk-rock chemical analyses. The enclaves containing gold mineralizations have predominantly greenish and yellowish colors whereas the enclave lacking the mineralizations are mostly blackish, brownish and gray in colors. It is aimed to evaluate gold endowment of Triassic metavolcanics and its enclaves in NNW part of Konya Turkey.

The samples have both igneous and metamorphic assemblages; the relict igneous phases are zoned plagioclase, euhedral sanidine, weakly pleochroic zoned clinopyroxene, 
hornblende and biotite in a hypocrystalline porphyritic texture. The metamorphic minerals are represented by white mica, chlorite, Na-amphibole, epidote, sphene, and opaque oxides. The enclaves have comparable mineralogy, but contain more mafic minerals and smaller phenocrysts than its host.

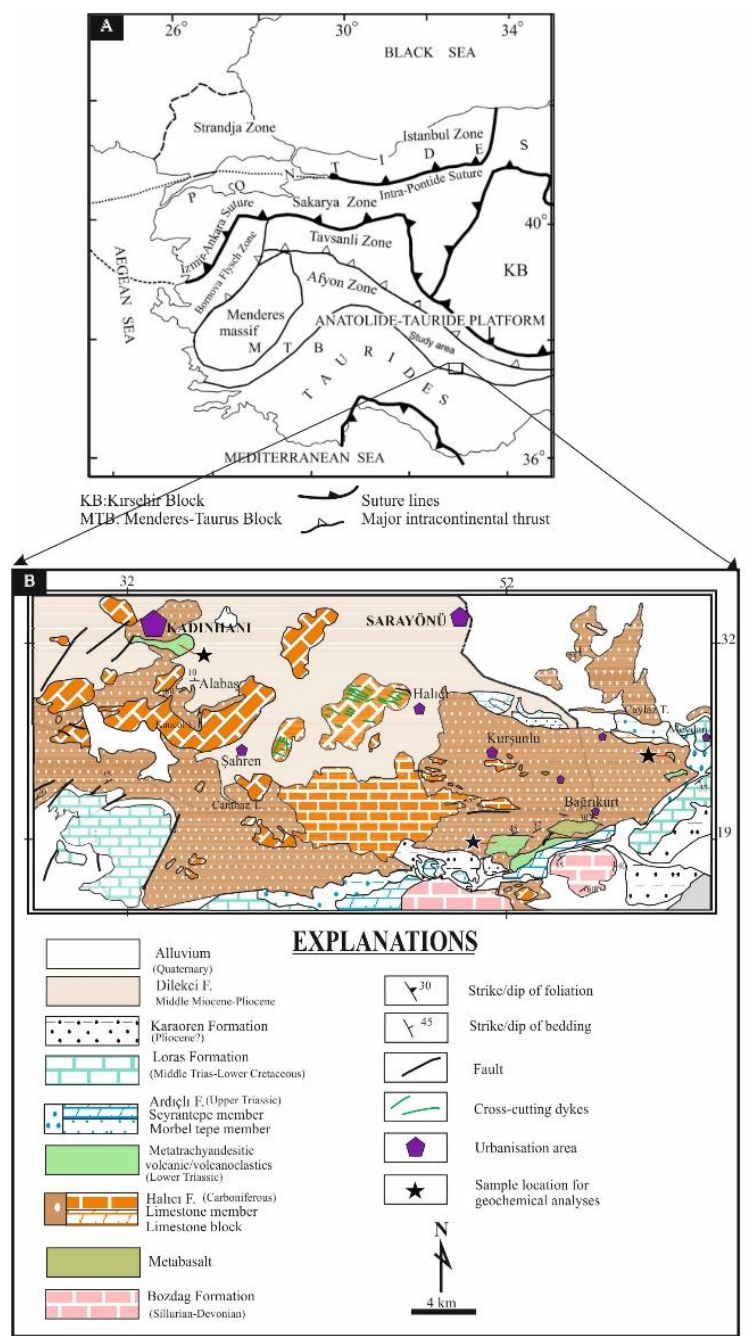

Figure 4. Location map (a) and geology map (b) of the study area [4],[5]

Gold bearing enclave and its host have undergone intense alteration so that almost no minerals can be identified under polarising microscope; mafic minerals were altered to chlorite, calcite and opaque minerals, and feldspars altered to sericite and calcite in spite of keeping their original shapes.

\section{GEOCHEMISTRY}

Bulk-rock chemical analyses of the gold-bearing metavolcanic rocks (5 samples) and theirs enclave (6 samples) are presented in Table 1, Both the host rocks and theirs enclave are mostly trachyandesite in composition (Error! Reference source not found.a), have intermediate $\mathrm{SiO}_{2}$ (enc.:64.7-67.4, host: 63.8-66.2 wt \%), low-high $\mathrm{Al}_{2} \mathrm{O}_{3}$ (12.5-15.6, 13.5-14.9 wt \%), low-intermediate $\mathrm{MgO}(0.8-2.1,0.7-2.0)$ and low $\mathrm{K}_{2} \mathrm{O}(1.3-2.7,1.4-1.8$ wt \%) contents. The enclave has lower Sr (629 ppm), Co (24 ppm), La (62.4 ppm) and Zr (235 ppm) content than its host (Sr: 702 ppm; Co: 35 ppm, La: 67.9 ppm; Zr: 252 ppm). 
In Harker variation diagrams (not shown), $\mathrm{SiO}_{2}$ increases with decreasing $\mathrm{MgO}, \mathrm{CaO}$ and $\mathrm{TiO}_{2}$, suggesting possible fractional crystallization of amphibole ( \pm olivine, pyroxene) and ilmenite, or amphibole ( \pm olivine, pyroxene) and ilmenite-bearing source.

Error! Reference source not found.b shows that the samples are enriched in large ion lithophile elements (LILEs; $\mathrm{Cs}$ and $\mathrm{Ba}$ ) and LREEs, with negative anomaly of $\mathrm{Nb}, \mathrm{Ta}, \mathrm{Sr}$ and Ti.

Table 1. Major and trace element analyses of the host rocks and their enclaves.

\begin{tabular}{|c|c|c|c|c|c|c|c|c|c|}
\hline & & Host rocks & $(\mathrm{n}=5)$ & & & & nclave $(\mathrm{n}=$ & 6) & \\
\hline & Sample & Averagen & & $\max$ & $\sigma$ & \begin{tabular}{|l|} 
Average \\
\end{tabular} & $\min$ & $\max$ & $\sigma$ \\
\hline & $\mathrm{SiO} 2$ & 65,6 & 63,8 & 67,0 & 1,08 & 66,3 & 64,7 & 67,4 & 0,94 \\
\hline & $\mathrm{Al} 2 \mathrm{O} 3$ & 14,0 & 12,7 & 14,9 & 0,83 & 14,2 & 12,5 & 15,6 & 0,99 \\
\hline & $\mathrm{Fe} 2 \mathrm{O} 3$ & 4,6 & 3,9 & 5,8 & 0,65 & 3,6 & 2,4 & 5,0 & 1,05 \\
\hline & $\mathrm{MgO}$ & 1,4 & 0,7 & 2,0 & 0,45 & 1,3 & 0,8 & 2,1 & 0,46 \\
\hline & $\mathrm{CaO}$ & 2,3 & 1,8 & 2,8 & 0,38 & 2,6 & 2,3 & 3,0 & 0,29 \\
\hline & $\mathrm{Na} 2 \mathrm{O}$ & 6,5 & 5,8 & 7,3 & 0,56 & 6,5 & 5,2 & 7,6 & 0,87 \\
\hline & $\mathrm{K} 2 \mathrm{O}$ & 1,6 & 1,4 & 1,8 & 0,14 & 1,7 & 1,3 & 2,7 & 0,50 \\
\hline & $\mathrm{TiO} 2$ & 0,9 & 0,8 & 0,9 & 0,03 & 0,8 & 0,8 & 0,8 & 0,02 \\
\hline & $\mathrm{P} 2 \mathrm{O} 5$ & 0,7 & 0,6 & 0,8 & 0,08 & 0,7 & 0,6 & 0,8 & 0,07 \\
\hline wt\% & $\mathrm{MnO}$ & 0,0 & 0,0 & 0,1 & 0,03 & 0,0 & 0,0 & 0,1 & 0,01 \\
\hline & $\mathrm{Cr} 2 \mathrm{O} 3$ & 0,0 & 0,0 & 0,0 & 0,00 & 0,0 & 0,0 & 0,0 & 0,01 \\
\hline & LOI & 1,7 & 1,4 & 2,0 & 0,24 & 1,6 & 1,2 & 2,0 & 0,24 \\
\hline & Sum & 99,5 & 99,2 & 99,7 & 0,19 & 99,7 & 99,6 & 99,8 & 0,05 \\
\hline & $\mathrm{Ba}$ & 1199,8 & 980,0 & 1860,0 & 332,37 & 1197,3 & 847,0 & 1673,0 & 295,69 \\
\hline & $\mathrm{Ni}$ & 11,6 & 6,0 & 22,2 & 5,81 & 10,2 & 5,4 & 16,3 & 4,28 \\
\hline & $\mathrm{Sc}$ & 14,0 & 12,0 & 16,0 & 1,67 & 14,0 & 13,0 & 16,0 & 1,15 \\
\hline ppm & $\mathrm{Be}$ & 4,4 & 3,0 & 6,0 & 1,20 & 4,7 & 0,0 & 8,0 & 2,56 \\
\hline & Co & 35,1 & 20,0 & 68,4 & 17,15 & 24,1 & 7,8 & 34,0 & 9,34 \\
\hline & $\mathrm{Cs}$ & 4,6 & 3,2 & 8,1 & 1,80 & 4,0 & 2,7 & 7,2 & 1,55 \\
\hline & $\mathrm{Ga}$ & 8,6 & 7,8 & 9,8 & 0,69 & 9,1 & 7,8 & 11,9 & 1,37 \\
\hline & $\mathrm{Hf}$ & 6,7 & 6,0 & 7,3 & 0,45 & 6,5 & 6,3 & 6,8 & 0,15 \\
\hline & $\mathrm{Nb}$ & 21,6 & 20,2 & 22,9 & 0,87 & 19,6 & 18,8 & 20,0 & 0,42 \\
\hline & $\mathrm{Rb}$ & 77,4 & 58,5 & 109,2 & 17,05 & 75,7 & 54,8 & 130,4 & 27,09 \\
\hline & Sn & 3,0 & 3,0 & 3,0 & 0,00 & 3,2 & 2,0 & 5,0 & 0,90 \\
\hline & $\mathrm{Sr}$ & 702,4 & 399,2 & 1221,8 & 282,12 & 628,6 & 397,7 & 912,1 & 200,92 \\
\hline & $\mathrm{Ta}$ & 1,4 & 1,2 & 1,6 & 0,14 & 1,3 & 1,2 & 1,4 & 0,08 \\
\hline & Th & 38,7 & 33,4 & 41,7 & 2,83 & 36,4 & 33,9 & 37,6 & 1,27 \\
\hline & $\mathrm{U}$ & 15,4 & 12,8 & 20,7 & 2,74 & 12,2 & 9,2 & 21,0 & 4,12 \\
\hline & V & 261,4 & 141,0 & 579,0 & 160,86 & 124,0 & 77,0 & 173,0 & 28,75 \\
\hline & W & 2,2 & 1,4 & 3,3 & 0,63 & 2,4 & 1,3 & 4,6 & 1,11 \\
\hline & $\mathrm{Zr}$ & 252,4 & 226,0 & 281,4 & 18,40 & 235,5 & 223,9 & 243,1 & 5,96 \\
\hline & $\mathrm{Y}$ & 25,9 & 24,4 & 28,9 & 1,56 & 23,9 & 21,2 & 29,9 & 2,92 \\
\hline & $\mathrm{La}$ & 67,9 & 63,3 & 73,0 & 3,51 & 62,4 & 57,8 & 66,5 & 2,74 \\
\hline & $\mathrm{Ce}$ & 143,3 & 132,3 & 171,4 & 14,78 & 126,6 & 113,4 & 136,3 & 6,92 \\
\hline & Lu & 0,3 & 0,3 & 0,3 & 0,03 & 0,3 & 0,2 & 0,3 & 0,02 \\
\hline & Mo & 6,1 & 3,2 & 14,7 & 4,41 & 2,3 & 1,0 & 6,1 & 1,75 \\
\hline & $\mathrm{Cu}$ & 738,0 & 393,7 & 1351,2 & 347,23 & 470,3 & 332,4 & 679,4 & 121,47 \\
\hline & $\mathrm{Pb}$ & 1621,9 & 412,2 & 3714,3 & 1170,02 & 323,5 & 116,4 & 529,0 & 123,34 \\
\hline & $\mathrm{Zn}$ & 16,2 & 11,0 & 25,0 & 4,71 & 13,7 & 10,0 & 19,0 & 3,20 \\
\hline & As & 17,5 & 4,0 & 29,2 & 10,30 & 7,7 & 3,4 & 12,1 & 2,98 \\
\hline & $\mathrm{Sb}$ & 0,6 & 0,3 & 0,8 & 0,23 & 0,3 & 0,2 & 0,4 & 0,10 \\
\hline & $\mathrm{Bi}$ & 34,5 & 24,0 & 53,4 & 12,09 & 60,6 & 15,4 & 129,1 & 44,43 \\
\hline & $\mathrm{Hg}$ & 0,0 & 0,0 & 0,1 & 0,04 & 0,0 & 0,0 & 0,1 & 0,02 \\
\hline & $\mathrm{Ag}$ & 1,7 & 0,4 & 3,6 & 1,29 & 0,6 & 0,2 & 1,1 & 0,34 \\
\hline
\end{tabular}

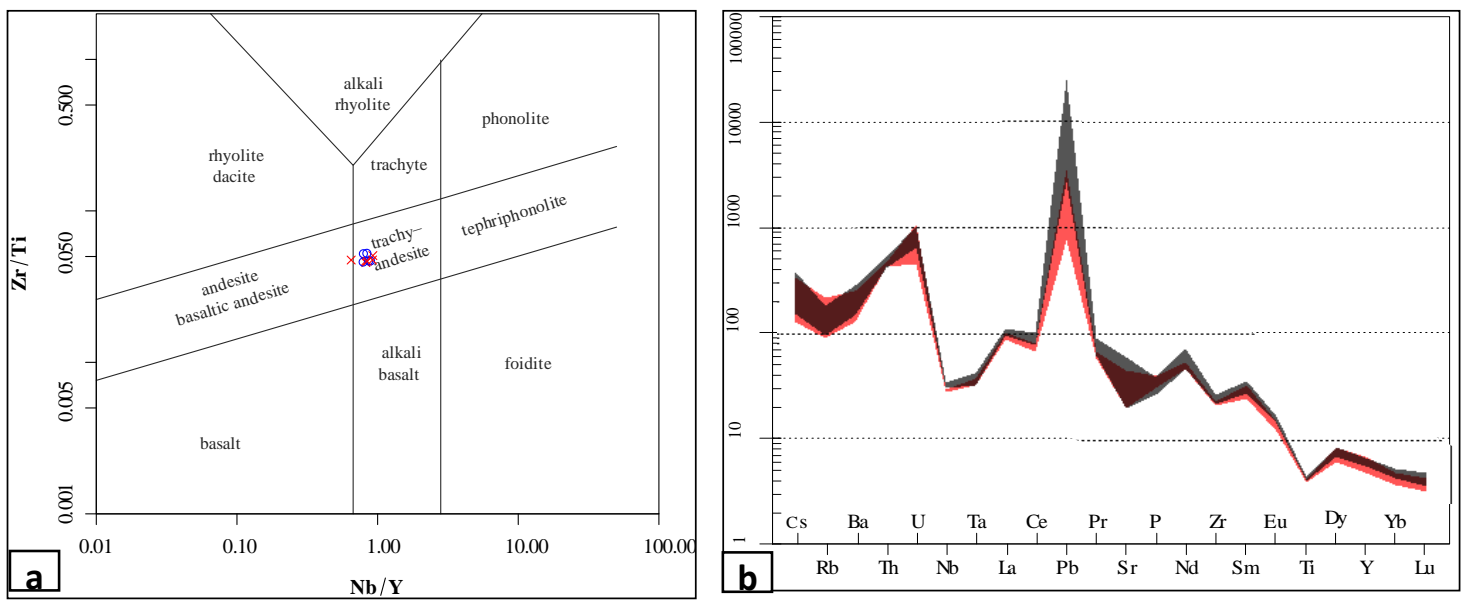

Figure 2. a) Nomenclature of the samples [6],

b)Primitive mantle [7] normalized trace element patterns of the samples, X: enclave, O: Host rocks 


\section{DISCUSSIONS\&CONCLUSIONS}

The samples have Low $\mathrm{Nb} / \mathrm{U}$ ratio (1.7 in enclave, 1.5 its host), which is different from ocean ridge basalt and oceanic island $\operatorname{arc}(\mathrm{Nb} / \mathrm{U}: 47,[8]$, but similar to the continental crust $(\mathrm{Nb} / \mathrm{U}=6.2 ;[9])$. However, both the enclaves and host rocks exhibit high $\mathrm{Nb} / \mathrm{Ta}$ ratio (enc 15.5, host 16.4 ) indicating a mantle origin as $\mathrm{Nb} / \mathrm{Ta}$ in mantle- and crustal derived magma are 17.5 and 11-12, respectively [10].

All samples exhibit usually co-linear variation in various Harker diagrams (not shown), which suggest that host rocks and its enclave are possibly co-products of identical magma. The samples are characterized by a LILE enrichment and are HFSE depletion, with characteristic negative $\mathrm{Nb}$ and $\mathrm{Ti}$ anomaly (Error! Reference source not found.b). These features may have been resulted from a subduction event [11], [12] and/or the crustal contamination during the ascent of the magma to the surface.

Geochemical analyses show that the samples are enriched in $\mathrm{Au}, \mathrm{Pb}, \mathrm{Cu}$ and $\mathrm{Bi}$. In Figure 5, $\mathrm{Au}$ shows negative correlation with $\mathrm{Pb}$ that is positively correlated with $\mathrm{Cu}$. $\mathrm{Au}$ also shows negative correlation with $\mathrm{Fe}_{2} \mathrm{O}_{3}$, but positive correlation with $\mathrm{TiO}_{2}$, suggesting rutile mineralization, and $\mathrm{Bi}$.

Neogene Erenlerdagi volcanic belt in Konya region is well-known known for gold occurrence [13]. Similarly, sulphide mineralization in the enclave, and gold mineralisation hosted by its andesite is also reported in western Tianshan, China [14].

Consequently, the enclave and its host are possibly co-product of a distinct mantlederived magma. The values determined by this study could indicate existence of an economic gold mining in the region in relation with Triassic volcanism and magma mixing/mingling, and need further studies.
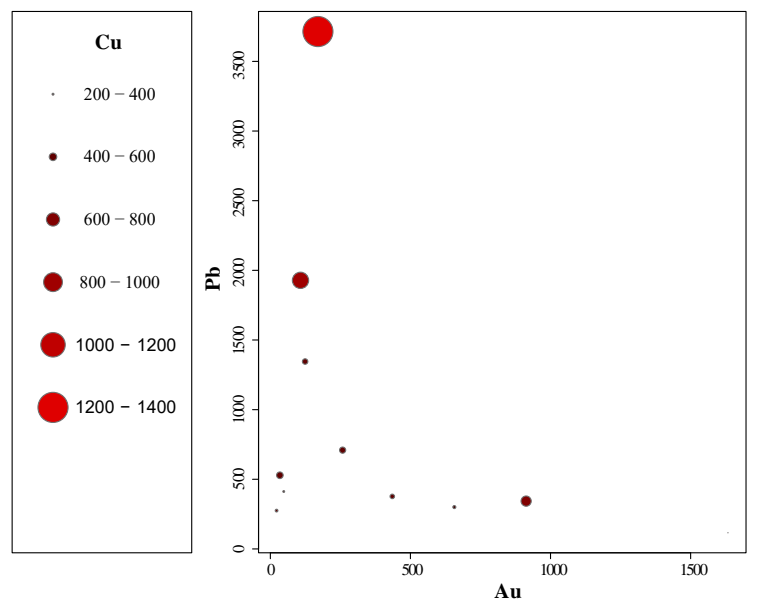

Figure 5. $\mathrm{Au}-\mathrm{Pb}-\mathrm{Cu}$ plot with circles of the samples

\section{Acknowledgements}

This work was supported in part by a grant from Selcuk University and Konya Technical University BAP (Bilimsel Arastırma Projeleri) Koordinatörlüğü, Konya/Turkey.

\section{REFERENCES}


[1] Okay AI. High-pressure/low temperature metamorphic rocks of Turkey., Geol. Soc. Amer. Mem, vol. 164, pp.338-348, 1986.

[2] Özcan A; Göncüoğlu MC; Turhan N; Şentürk K; Uysal Ş, Işık A. Konya-Kadınhanı-Ilgın dolayının temel jeolojisi (in Turkish) (1990). MTA Genel Müdürlüğü Jeoloji Etütleri Dairesi.

[3] Janković S. The copper deposits and geotectonic setting of the Thethyan Eurasian Metallogenic Belt, Mineralium Deposita, vol. 12, 1, pp.37-47, 1977.

[4] Akal C; Candan O; Koralay OE; Oberhansli R; Chen FK, Prelevic D. Early Triassic potassic volcanism in the Afyon Zone of the Anatolides/Turkey: implications for the rifting of the NeoTethys, International Journal of Earth Sciences, vol. 101, 1, pp.177-194, 2012.

[5] Goncüoğlu MC. GEOLOGY OF THE KÜTAHYA-BOLKARDAĞ BELT MTA Enstitusu Dergisi, vol. 142, pp.223-277, 2011.

[6] Pearce JA. A User's Guide to Basalt Discrimination Diagrams. In DA Wyman (Ed.), Trace Element Geochemistry of Volcanic Rocks: Applications for Massive Sulphide Exploration (Vol. 12, pp. 79-113). Canada: Geological Association of Canada.1996.

[7] Mcdonough WF, Sun SS. The Composition of the Earth, Chemical Geology, vol. 120, 3-4, pp.223-253, 1995.

[8] Hofmann AW; Jochum KP; Seufert M, White WM. Nb and Pb in oceanic basalts: new constraints on mantle evolution, Earth and Planetary Science Letters, vol. 79, 1, pp.33-45, 1986.

[9] Rudnick RL, Fountain DM. Nature and Composition of the Continental-Crust - a Lower Crustal Perspective, Reviews of Geophysics, vol. 33, 3, pp.267-309, 1995.

[10] Green TH. Significance of $\mathrm{Nb} / \mathrm{Ta}$ as an indicator of geochemical processes in the crustmantle system, Chemical Geology, vol. 120, 3-4, pp.347-359, 1995.

[11] Fitton JG; James D; Kempton PD; Ormerod DS, Leema WP. The role of lithospheric mantle in the generation of late Cenozoic basic magmas in the western United States, J. Petro, vol., pp.331-349, 1988.

[12] Pearce JA; Bender JF; Delong SE, et al. Genesis of Collision Volcanism in Eastern Anatolia, Turkey, Journal of Volcanology and Geothermal Research, vol. 44, 1-2, pp.189-229, 1990.

[13] DJ H; RP F; B Y, SD R. The Inlice High-sulphidation Epithermal Gold Discovery: Defining a Potential New Gold Belt in Turkey., Digging Deeper, vol. 1-2:, pp.113-116 2007.

[14] Zhao X; Xue C; Symons DTA; Zhang Z, Wang H. Microgranular enclaves in island-arc andesites: A possible link between known epithermal $\mathrm{Au}$ and potential porphyry $\mathrm{Cu}-\mathrm{Au}$ deposits in the Tulasu ore cluster, western Tianshan, Xinjiang, China, Journal of Asian Earth Sciences, vol. 85, pp.210-223, 2014. 